\title{
Global sourcing: new research and education agendas for apparel design and merchandising
}

\author{
Jung Ha-Brookshire*
}

*Correspondence:

habrookshirej@missouri.edu

University of Missouri,

Columbia, MO, USA

\section{照 Springer}

\begin{abstract}
In response to the dominance of global sourcing in the apparel industry within developed economies, this paper illustrates how the topic of global sourcing could help direct agendas for future research and education within the apparel discipline. By reviewing major functions of apparel design, product development, merchandising, and marketing in consideration of global sourcing, this paper shows how global sourcing could help designers and product developers make better decisions of fiber choices, better understand tradeoffs users may make between different raw materials, and become more aware of product performance requirements and design compliance issues. It illustrates how research on global sourcing would help merchandisers become more effective forecasters, planners, and implementers in this highly unpredictable marketplace. Marketing professionals will also learn to work with global sourcers to ensure transparency and integrity of their messages within the legal and ethical frameworks. A discussion on future research questions and educational goals follows.
\end{abstract}

Keywords: Global sourcing, Supply chain management, Education agenda, Research agenda, Apparel

\section{Introduction}

Sourcing itself is not new. Even before the Industrial Revolution, people sourced things they needed. Back then, women were in charge of producing clothing for the family (Wilson 2002). When women needed certain materials to complete clothing construction, they sourced the materials from the neighbors, friends, family, and other entities. Acquiring the right materials to complete whatever tasks at hand is not a new phenomenon in human history as one can see from the history of bartering. Then, the significant changes occurred in the way human exchange materials and finished goods, during and after the Industrial Revolutions that shifted manufacturing of clothing from home to factories. Women no longer made clothing at home. They started purchasing ready-made clothing from the marketplace (Idem). To meet this new demand, factories producing a large scale of clothing were established, and these factories developed business clusters in which both suppliers and customers co-exist to facilitate efficient raw material movements and transactions (Ha-Brookshire 2015). Even at this industrial level, sourcing the

(c) 2015 Ha-Brookshire. This article is distributed under the terms of the Creative Commons Attribution 4.0 International License (http://creativecommons.org/licenses/by/4.0/), which permits unrestricted use, distribution, and reproduction in any medium, provided you give appropriate credit to the original author(s) and the source, provide a link to the Creative Commons license, and indicate if changes were made. 
right materials and skills to achieve business goals was again a routine business activity (Ha-Brookshire 2015).

Global sourcing, however, is a much newer business activity compared to domestic sourcing. The popularity of global sourcing has taken off after World War II as world trades accelerated (Dicken 2011). Through the development of technology and transportation, trading raw, unfinished, or finished products across borders has become much easier than in the past (Idem). Access to low-cost labor and abundant raw materials intensified the movement of manufacturing sites from developed countries to developing countries in the late 20th century (Cook 2007). Today, many consumer product industries are engaged in and dependent on global sourcing. The current apparel industry is the most globalized of all (Dicken 2011); global sourcing is one of the key factors of the globalization of the industry.

This trend in the world market fundamentally changed business activities within the industry. The nature of jobs, the objectives of businesses, and internal and external factors of business strategies have significantly changed to respond to new market environments that apparel companies have faced (Ha-Brookshire and Dyer 2008). This globalization trend also changed the ways consumers perceive, use, and evaluate products in the marketplace. Consumers in developed countries are used to finding apparel made overseas than in the past. Multi-national or hybrid products (the products made in multiple countries) have also become popular (Chao 2001). The country of manufacturing origin is now thought to have less effect on consumer perceptions than the country of brand or design origin (Essoussi and Merunka 2007). More often than not, the origin of raw materials became more important than the origin of manufacturing (Insch and McBride 1998).

Given these fundamental changes that both industry professionals and consumers face in today's apparel marketplace in developed countries, researchers argue the topics of research, education, and even policies must also change (Ha-Brookshire and Dyer 2009; Jones and Hayes 2004; Scheffer and Duineveld 2004; Taplin and Winterton 2004). In response, researchers investigated in the areas of sourcing strategies, trade policy issues, and outcome analysis of successful global sourcing (Lu and Ha-Brookshire 2009; Su et al. 2009; Seshadri 2005). These studies look at global sourcing itself as a core topic of investigation. However, an investigation on how global sourcing could affect other business activities has been limited. That is, we knew little about how global sourcing affects decision-making processes of merchandising, product development, or even marketing. In this light, this paper is organized to offer insights into what global sourcing is and how global sourcing influences other business activities. Though this study focuses on a comparison of the role of global sourcing in the apparel industry and the apparel discipline, future research questions and new educational goals are discussed within the realm of apparel design, product development, merchandising, and marketing.

\section{Background}

\section{Global apparel industry}

The re-structuring of the world's apparel industry in the last decades has been well documented. Developed countries are major importers of apparel produced in developing countries. In 2013, the world apparel import trade accounted for US $\$ 481$ billion. The 
United States was the leading apparel importer with US $\$ 91$ billion, followed by Germany (US $\$ 35.5$ billion), Japan (US $\$ 33.6$ billion), France (US $\$ 23.4$ billion), and United Kingdom (US $\$ 22.8$ billion) (Idem). In the same year, the world apparel export trade accounted for US $\$ 460$ billion, and China was the leading apparel exporter with US $\$ 177.4$ billion (Idem). Italy (US $\$ 23.7$ billion), Bangladesh (US $\$ 23.5$ billion), and Hong Kong (US $\$ 21.9$ billion) were the next leading apparel exporters (Idem).

Today's landscape of the global apparel industry indicates that developed countries such as the US, Germany, Japan, France, and the UK are engaged in apparel "import" activities while exporting countries such as China, Italy, Bangladesh, and Hong Kong are involved in apparel "export" activities. ${ }^{1}$ This apparel import/export trend is a significant shift since 1963, when the total value of world apparel trade was only $\$ 2.2$ billion, and most importantly, of which only $14 \%$ of US $\$ 2.2$ billion was generated by developing countries (Appelbaum and Christerson 1997; Ha-Brookshire and Dyer 2008). That is, in the early 1960s, most developed countries were engaged in apparel exports, while, today, they are now the world's leading apparel importers.

\section{Role of global sourcing in the industry}

To import apparel from other countries to a home country, some ones, some companies, or some entities in apparel import countries must exist to facilitate apparel import between the home country and foreign manufacturers. During the shift of global apparel manufacturing sites, apparel companies in developed countries have also changed from manufacturing/export-oriented to retailing/import-oriented activities (Dicken 2011; HaBrookshire and Dyer 2008). During this shift, global sourcing emerged as a new business activity within the developed countries to enable apparel imports for apparel companies in home countries (Ha-Brookshire and Dyer 2008).

The case of the South Korean apparel import/export trends shows a prime example of such a shift within the apparel industry. South Korea, one of the biggest apparel exporters in the world in the late 20th century, is now the 13th largest apparel importer in the world. In 2013, South Korea imported US $\$ 7.5$ billion worth of apparel (Idem). The amount of apparel imports by South Korea is three times greater than its apparel exports of US $\$ 2.1$ billion in 2013 (Idem). That is, the South Korean apparel industry can now be said to be an apparel importer rather than exporter. In other words, global sourcing is and should be a more prevalent business activity than apparel manufacturing in today's South Korean apparel industry.

Formally, sourcing refers to a set of business processes and activities by which businesses acquire and deliver components or fully finished products from outside the organization (Ha-Brookshire 2015). If the sourcing activities take place beyond national borders, they become global sourcing (Idem). Sourcing includes all aspects of business activities involved in acquiring parts of full components outside the organization. HaBrookshire (2015) explains that typical sourcing jobs include finding the right suppliers who could produce the products at the right time and the right cost. However, she further argues that companies may source more than just low-cost manufacturing capacity.

${ }^{1}$ Please note here that Italy is also a leading apparel import country as they imported apparel worth up to $\$ 15.7$ billion in 2013, as the 7th highest apparel import country in the world. That is, Italy is one of the unique countries that both import and export apparel to the world to a significant extent. 
Specific talents and knowledge, such as design skills and legal expertise, can also be sourced. Even, business relationships can be sourced if they are strategically necessary for the company's long-term goals.

When sourcing takes place in the global market, coordinating various sourcing activities becomes more complicated. The suppliers (whether they are raw material producers, designers, or legal experts) might be located in multiple foreign countries, and each country may have different international trade regulations and policies. Therefore, sourcers must navigate through various trade rules in order to coordinate the importing and exporting of various materials, resources, and products (Ha-Brookshire 2015). In addition, sourcers may need to coordinate complex supply chain ${ }^{2}$ functions that might exist throughout the world, in order to produce products at the price that the merchandisers set, in the quality that the designers envisioned, in the condition that the marketers have communicated with the consumers in the home country, and in a legal and ethical manner (Idem).

To achieve this objective, global sourcers must closely work with designers/product developers, merchandisers/marketers, and foreign manufacturers/suppliers (Ha-Brookshire 2015). In this light, global sourcers are the key to pulling all fragmented information together, executing production around the world, and bringing the finished goods to the home country for sale. Global sourcers play a central role in business activities within the import-oriented apparel industry (Ha-Brookshire and Dyer 2008).

\section{Role of global sourcing in education}

As the nature of business activities changes, the needs for new research findings and curricula also change. Fair et al. (1990) argued that the most important mission for undergraduate textiles and clothing curricula is to provide what the industry wants from future workforce so students could acquire jobs in the industry. Although the research was over 20 years old, this statement still holds certain values in today's society. "Industry-readiness" of curricula has become even more emphasized under President Obama's administration in the United States. For example, in order for any educational institutions to receive US federal grants, they must track and show positive data on workforce preparation and job placement. Under this initiative, US Education Department has been working on creating a framework for rating US colleges and universities. The framework includes three key metrics related to access, affordability, and student outcomes (e.g., graduates' employment and earnings data) (Anderson 2014). The consensus is that this policy will change the way US colleges and universities focus and operate.

Although some people are concerned with too much focus on employment and job placement as the goals of higher education, we also understand that this trend will not go away or become less important in the future. A question here is then, what type of research findings and teaching content must the apparel discipline, particularly in developed countries with the import-oriented apparel industry, produce so the discipline can help yield industry-relevant new knowledge and an industry-ready future workforce? In this paper, part of the answers to this question was explored through the role of global

${ }^{2}$ A supply chain refers to "a network of materials, information, and services processing links with the characteristics of supply, transformation, and demand" (Chen and Paulraj 2004, p. 119). 
sourcing within the industry, with a hope to provide frameworks to researchers and educators.

As previously mentioned, global sourcing in the apparel industry coordinates business activities between design/product development and merchandising/marketing, while executing foreign apparel production and importing. Figure 1 is a simplified version of two major areas of the apparel industry that are currently researched and taught in today's high education environments. The figure shows that global sourcing facilitates various business functions between design/product development and merchandising/ marketing.

In this paper, apparel design refers to creative processes of developing an apparel product line to meet the target market's needs and wants. Apparel product development refers to the process of engineering apparel products so the finished products can be serviceable, producible, and salable with certain profits (Kunz 2009). Merchandising is defined as planning, developing, and presenting apparel product lines for the target markets, including plans of prices, styles, assortments, and sales (Idem). Finally, marketing is concerned with facilitating exchanges and relationships between products and consumers by creating values and satisfying target consumers' needs and wants (Bickle 2011). For small companies, all of these functions could be carried out by one or a few people within the company. However, typically, in large companies, these functions are divided into different groups/teams of people, and each individual is focused on a few specific tasks. With the main domains of design, product development, merchandising, and marketing in mind, the role of global sourcing in research and education with each of these functions is explored next.

\section{Research and educational opportunities in global sourcing} Apparel design/product development vs. global sourcing

In the industry, decisions on apparel design and product development are made with close interactions with global sourcers. First, fiber contents (or raw material contents) not only affect the cost of the total production but also environmental impacts during the production. Let's assume that a designer decided a fiber content to be a natural fiber,

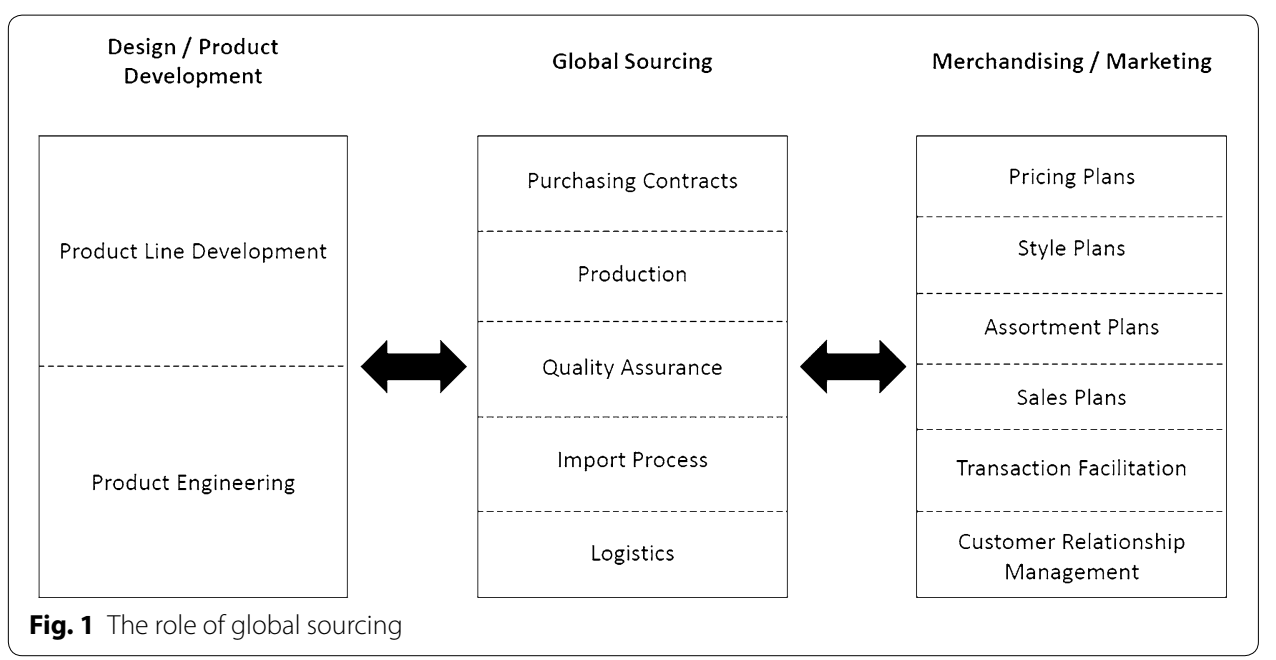


such as cotton, rather than a synthetic fiber, such as polyester, for a men's knit shirt for the upcoming season. This simple decision could make a huge impact on retail prices. For example, in 2011, cotton prices had quadrupled since 2002 (National Cotton Council of America 2012); the cost difference between polyester and cotton fabric was so significant that the change in fiber content was not something that the design team could simply make without consulting global sourcers. Sourcers may not be able to produce products for which the company planned. Instead, the sourcer may suggest a cotton/polyester blend fabric for knit shirts. In addition, the change in fiber content also affects the duty rates when the global sourcer imports the finished products from foreign countries. In the case of the United States, men's knit shirts with a majority of cotton fibers are subject to $19.7 \%$ of the import cost as duty. If the same shirts are made out of synthetic fibers, they will be subject to $32 \%$ of duty rate (Idem). These are important factors that the design team must consider and work with the sourcing team to find the optimal point between fiber choice and cost to produce and import. Different countries have different duty assessment policies and duty rates. One strategy in fiber content may work for one country but may not work for another country with different duty rates. Therefore, sourcers and design team must assess the market of the finished goods comprehensively before making final decisions on fiber choices.

This role of global sourcing during the design stage informs researchers and educators in a few different ways. For example, consumers' attitudes/preferences toward fabrics/materials with different fiber components could be interesting research to conduct. Although textile scientists and textile engineers research various physical functions and serviceability of textiles for different end users, we do not know enough about how consumers make tradeoffs between the differences in comfort, functionality, and price that may stem from different fiber blends in the raw materials for different types of end products. What would be the most optimal way to choose fiber contents that are serviceable and producible within the budget constraints without jeopardizing the designers' visions for that product? Are there any cultural differences in these topics? If so, what do they look like? To these questions, researchers could conduct empirical research that will show the optimal point of tradeoffs between comfort, functionality, and price. Educators could also facilitate student learning by challenging design students to consider these facts while making raw material choices.

Second, global sourcers may also influence the material development stage. Suppose the desired fabric choice of a given product is extremely expensive and is almost impossible to be used for a target market to which a design is intended. Global sourcers could help find alternative fabric options that could meet the designer's vision yet still be producible and affordable for the target market. Although this type of negotiation between quality and affordability frequently takes place in the industry, little research is conducted as to how to facilitate and evaluate such negotiations. How important is the quality of the raw materials in different market segments-designer label, bridge, better, mid, and mass markets? What are the consumers' expectations on the raw material quality in different market segments? How do they differ in different market segments? What type of interaction effects exist? What are the thresholds of high or low quality of raw materials that consumers will accept at the price for which they are paying? Are there any cultural differences in these topics? If so, what do they look like? Findings on these research 
questions will then be able to inform design students to make deliberate decisions on raw material selections when they design. They could also help design students develop innovative solutions to provide the values that consumers want at different level of price ranges, which often requires negotiation between quality and affordability.

Third, designers and product developers must also consider product performance requirements and compliance issues when developing new apparel product lines. After all, if the products are not designed and produced legally and safely, they will not be successfully sold in the marketplace. In the case of the United States, most apparel products are subject to the Flammable Fabrics Act of 1953. Children's sleepwear is particularly tightly regulated by this law. If designers and product developers want to have more freedom in fabric choices for children's sleepwear (that is they want to use fabrics that may not meet the flammability guidelines for this product category), they must design the children's sleepwear within the tight-fitting garment guidelines specifically published by US Consumer Product Safety Commission (National Archives and Records Administration 2012a). That is, in this case, the fabric choice for children's sleepwear affects the garment shapes and sizes, and therefore, the designers and product developers must be aware of this type of laws and balance the needs of aesthetics and function.

Similarly, the US government regulates small parts for children's apparel for choking hazard issues (National Archives and Records Administration 2012b). All products marketed to children must go through extra safety-related inspections and tests under the Consumer Product Safety Improvement Act of 2012. Outdoor apparel products may require different functional and aesthetic needs, while luxury products may appeal to completely different sets of consumers' needs and wants. During this design/product development stage, global sourcers and designers work together to finalize the designs that could be produced safely and made to be legally compliant, while keeping the design elements creative and fresh.

Again, this type of industry issue also offers new research and education opportunities. What are the theoretical frameworks that would help explain users' choices between functionality and aesthetics? Do users have different tolerance or acceptance levels for functionality for aesthetic apparel, or vice versa? Why and why not? How designers develop aesthetic skills, while keeping functionality in mind, or vice versa? How do students learn functions of the apparel products when they are not the users of such products (e.g., outdoor apparel that is highly functional in certain situations)? How do we ensure our students will think about product safety issues while learning creative design? What drives such learning, and what are the best practices? How is the creativity of design students developed or hindered through such constraints imposed by external entities? Are there any cultural differences in these topics? If so, what do they look like?

\section{Apparel merchandising/marketing vs. global sourcing}

One of the key goals of the merchandising function is to plan apparel products in the styles that target consumers would like to have, at the price they are willing to pay, in the sizes they need, and at the time they want to buy. Precise forecasting is one of the most important secrets to success in any apparel company in today's market environment. When demand is too unpredictable, postponement is one way to deal with unstable demands. Postponement refers to delaying certain processing or distribution activities 
until more precise information on demands is available, and is one of the supply chain management strategies often discussed in the literature.

For example, if a merchandiser is not certain about the color assortment plans due to fast-changing consumers' tastes, the merchandiser and the sourcers could potentially delay dyeing processes. The delay could be made at the fabric manufacturing level in which grei goods are made, but dyeing will not take place until more accurate color assortments are forecasted. The delay could also be made at the garment manufacturing stage in which all blank shirts are made with fabrics that are not dyed and finished. Once more accurate color forecasting is made, then the color could be added in a garment form, resulting in garment dyed apparel products. This type of postponement can be made with any sort of supply chain related decision making. At the distribution level, certain colors can be shipped in higher quantities to certain regions where the demand for that color of shirt is high.

Certainly, effective postponement strategies are not made by one person. Not all processes and distribution activities can be postponed at any time or all the time. A tradeoff between the cost and benefit of postponement must be made. Some postponement may require extra storage facilities to keep unfinished products safe and clean. Some postponement may disrupt workload flows that may arise from shorter response times between demand forecasting and actual production/distribution activities. During this tradeoff analysis, discussion amongst the merchandising team, sourcing team, logistics team, and foreign suppliers must take place to arrive at the most efficient yet flexible supply chain to take advantage of fast-changing consumer demands.

In the research and education setting, one may investigate how effectively merchandisers' plan and forecast future demands-and, therefore, possibly strategically postpone certain processes or distribution activities. Risks in demand forecasting also differ amongst product categories. For example, women's and junior wear markets are under high pressure to offer the latest trend, while the latest trend is not as important in the sleepwear and men's wear industries. What are the common practices and rules of thumbs for the women's and junior wear markets to develop and implement the merchandising plans trends? How do they differ from the men's and the sleepwear markets? What type of different risks do these markets offer to merchandisers and global sourcers? Case studies on successful (or unsuccessful) demand forecasting strategies in different segments of the apparel market, such as fast fashion, luxury, or mass market, could also be interesting. How do all of these differences affect merchandising and potential postponement strategies? Are there any cultural differences in these topics? If so, what do they look like?

In addition, it would be also fruitful to empirically investigate effective contingency plans for early or late delivery of the products in various market segments (e.g., fast, mass, luxury, men's, women's, etc.). The impact of timing of product availability to consumers on sales or demand satisfaction could help assess a tradeoff between cost and benefit of postponement strategies. In this case, educators do not stop at teaching students how to create initial sales, assortment, and any other merchandising plansalthough this is a typical curriculum content in most merchandising classes. In real-life business setting, initial plans are almost always revised due to changes in marketplaces. Therefore, educators could challenge students to develop alternative strategies when 
certain portions of the initial merchandising plans must be changed-whether it is a delivery time, color assortment, size assortment, or even sell-through plans.

Second, marketing professionals and global sourcers must work together in order for marketing campaigns (a) to be legal and compliant, and (b) to build and enhance the relationship between consumers and the apparel company/brand in the most effective way. In today's market environment in which consumers want to know how and where products are made (Bhaduri and Ha-Brookshire 2011), accurate and transparent marketing messages to consumers are critical. In the United States, any type of corporate communications is obligated to avoid false advertisements (Stevens 2003). Repeated untrustworthy messages from companies are known to create negative schemas, attitudes, and purchase intentions amongst consumers (Ha-Brookshire and Bhaduri 2014). Negative schemas in consumers' minds are thought to have a significant impact on their future actions since schemas are "representations of experience" stored in consumers' memory that guide their future actions, perceptions, and thoughts (Mandler 1982, p. 3). That is, once a negative schema is formed toward a certain company, it is extremely difficult to change it. Therefore, marketing professionals must be careful with what they are claiming and must claim what is consistent with how and where products are made and distributed for a positive long-term effect.

One of the key examples of failure in communication between marketers and global sourcers is found in the usage of bamboo in fiber content. In 2010, the US Federal Trade Commission (2010) warned 78 retailers nationwide that the retailers may not be able to label and advertise products as "bamboo." Rather, they needed to be communicated as "rayon made of manufactured rayon fiber". The FTC further explained that these retailers advertised bamboos as "ecoKashmere", "Pure Bamboo", "Bamboo Comfort", "BambooBaby". They even made other deceptive "green" claims in that bamboo fibers have the bamboo plant's antimicrobial properties, are made in an environmentally friendly way, and are biodegradable. Of course, anyone who knows how bamboo fibers are actually made would know none of these claims is true. In the apparel company setting, it would be the global sourcer who truly knows how bamboo fibers are made and what types of benefits these fibers would offer to consumers. Yet, the marketers proceeded with false claims and ended up breaking the laws by claiming something that is not true. This type of false advertisement also creates distrust between consumers and the companies (HaBrookshire and Bhaduri 2014).

In this light, more research is recommended to discover the relationship between marketing claims and consumer attitudes, intention, and behavior toward such claims. Particularly, the intention of false claims/advertisements is known to affect consumers' schemas and attitudes to a much larger degree than the false claims/advertisements made by mistake (Ha-Brookshire and Bhaduri 2014). Then, how do consumers perceive, formulate, and remember the company's ill intentions? What is the impact of ill intentions on consumers' future acts and behavior? Are there any cultural differences in these topics? If so, what do they look like? While many researchers assess the impact of companies' positive acts (such as, the usage of sustainable materials, socially responsible processes, and so on), in general, we lack understanding of how consumers respond to companies' negative practices. 
In addition, research on how to formalize routine and effective communications between marketers and global sourcers would be extremely beneficial. In this light, educators may want to challenge marketing students to develop plans to ensure the transparency and integrity of marketing messages during the marketing communication development stage. What information or evidence is required for the marketing team to claim/advertise certain things (e.g., Can we really say this jacket is water proof? Or, should we say water-repellent? What are the legal definitions of such terms, and what evidence must I possess before making such claims)? What regulations, legal frameworks, and policy guidelines do students have to check before making certain claims/ advertisements? What claims are legally compliant while they may be unethical or unsustainable? What claims are ethical or sustainable while the laws do not allow making such claims? What are the roles of global sourcers in this case and how can global soucers help the marketing team to preserve the transparency and integrity of marketing claims? Are there any cultural differences in these topics? If so, what do they look like?

\section{Conclusions}

In response to the dominance of global sourcing activities in the apparel industry within developed economies (Ha-Brookshire and Dyer 2008), this paper illustrates how the content of global sourcing could help direct agendas for future research and education within the apparel-related discipline. Preparing students to be industry-ready is an unavoidable force that the discipline will face in the future. Given that most business activities are shifting from manufacturing to importing and retailing (Idem), it is clear that apparel academicians must also be up to date with industry activities, and provide researching findings and educational opportunities for future workforce.

By going through major functions of apparel design, product development, merchandising, and marketing in consideration of global sourcing, this paper presented how global sourcing could enhance research and teaching agendas. Knowledge of global sourcing would help designers and product developers make better decisions of fiber choices, better understand tradeoffs users may make between different raw materials, and more aware of product performance requirements and design compliance issues. All of this knowledge will help designers and product developers become truly the experts of the products that they are designing and developing. Knowledge of global sourcing would also help merchandisers become more effective forecasters, planners, and implementers in this highly unpredictable marketplace. Marketing professionals will also learn to work with global sourcers to ensure the transparency and integrity of their messages within the legal and ethical frameworks.

For many reasons, the apparel discipline has been divided into two major tracksdesign/product development and merchandising/marketing. This is and has been an effective and efficient approach to organize curricula with limited faculty and financial resources. However, the division has also created an unexpected gap between the two tracks. Global sourcing can be the connector between the two as it is in the industry. Without a global sourcing team, there are no final products to sell. Without a global sourcing team, there are no final products that carry designers' creative visions. After all, global sourcers are the ones who force dialogues and facilitate negotiations between the two tracks. It is time for the apparel academicians to delve into researching and teaching 
global sourcing in their existing research streams and teaching curricula whether they are on the design/product development or merchandising/marketing track.

\author{
Compliance with ethical guidelines
}

Competing interests

The author declares that she has no competing interests.

Received: 6 January 2015 Accepted: 5 August 2015

Published online: 02 September 2015

\title{
References
}

Anderson, N. (2014). Education Department releases framework for rating US colleges and universities. Retrieved January 5, 2015, from the The Washington Post, from http://www.washingtonpost.com/local/education/educationdepartment-releases-framework-for-rating-us-colleges-and-universities/2014/12/18/b8d4a4b8-86e4-11e4-9534f79a23c40e6c_story.html.

Appelbaum, R. P., \& Christerson, B. (1997). Cheap labor strategies and export-oriented industrialization: some lessons from the Los Angeles/East Asia apparel connection. International Journal of Urban and Regional Research, 21, $202-217$.

Bhaduri, G., \& Ha-Brookshire, J. (2011). Do transparent business practices pay? Exploration of transparency and consumer purchase intention. Clothing and Textiles Research Journal, 27(2), 135-149.

Bickle, M. C. (2011). Fashion marketing: theory, principles, and practice. New York: Fairchild.

Chao, P. (2001). The moderating effects of country of assembly, country of parts, and country of design on hybrid product evaluations. Journal of Advertising, 30(4), 67-81.

Chen, I. J., \& Paulraj, A. (2004). Toward a theory of supply chain management: the constructs and measurements. Journal of Operations Management, 22, 119-150.

Cook, T. (2007). Global sourcing logistics: how to manage risk and gain competitive advantage in a worldwide marketplace. New York: American Management Association.

Dicken, P. (2011). Global shift: Reshaping the global economic map in the 21st century (6th ed.). New York: Guilford press.

Essoussi, L., \& Merunka, D. (2007). Consumers' product evaluations in emerging markets: does country of design, country of manufacture, or brand image matter? International Marketing Review, 24(4), 409-426.

Fair, N. B., Hamilton, J. A., \& Norum, P. S. (1990). Textile knowledge for merchandising professionals: significance for pedagogy in clothing and textiles. Clothing and Textiles Research Journal, 8(2), 29-37.

Ha-Brookshire, J. (2015). Global sourcing in the textile and apparel industry. Upper Saddle River: Pearson.

Ha-Brookshire, J., \& Bhaduri, G. (2014). Disheartened consumers: impact of malevolent apparel business practices on consumers' heart rates, perceived trust, and purchase intention. Fashion and Textiles, 1(10), 1-12.

Ha-Brookshire, J., \& Dyer, B. (2008). Apparel import intermediaries: The impact of a hyper-dynamic environment on US apparel firms. Clothing and Textiles Research Journal, 26(1), 66-90.

Ha-Brookshire, J., \& Dyer, B. (2009). Framing a descriptive profile of a transformed apparel industry: apparel import intermediaries in the United States. Journal of Fashion Marketing and Management, 13(2), 161-178.

Insch, G., \& McBride, J. (1998). Decomposing the country-of-origin construct: an empirical test of county-of-design, country-of-parts, and country-of-assembly. Journal of International Consumer Marketing, 10(4), 69-91.

Jones, R. M., \& Hayes, S. G. (2004). The UK clothing industry: extinction or evolution? Journal of Fashion Marketing and Management, 8, 262-278.

Kunz, G. I. (2009). Merchandising: theory, principles, and practice (3rd ed.). New York: Fairchild.

Lu, S., \& Ha-Brookshire, J. (2009). Regional production network led by the US textile industry and the impact of the 2006-2008 US-China Textile Agreement. Journal of Textile and Apparel Technology and Management, 6(2), 1-11.

Mandler, G. (1982). The structure of value: accounting for taste. In M. S. Clark \& S. T. Fiske (Eds.), Affect and cognition: THE 17th annual carnegie symposium (pp. 3-36). Hillsdale: Lawrence Erlbaum Associates.

National Archives and Records Administration. (2012a). Electronic code of federal regulations. Retrieved June 5, 2012, from http://ecfr.gpoaccess.gov/cgi/t/text/text-idx?sid=f663a1a1668cc7aa41c5e5dba17fecc4\&c=ecfr\&tpl=/ ecfrbrowse/Title16/16cfrv2_02.tpl. Accessed 15 Jan 2015.

National Archives and Records Administration. (2012b). Part 1501. Retrieved from Title 16: commercial practices. http:// ecfr.gpoaccess.gov/cgi/t/text/text-idx?c=ecfr\&sid=91c1 c52ef39e75df4cb2b91 bffccff1 1\&rgn=div5\&view=text\&no de $=16: 2 \cdot 0 \cdot 1 \cdot 3 \cdot 72 \& i d n o=16$. Accessed 15 Jan 2015.

National Cotton Council of America. (2012). Monthly prices. Retrieved June 6, 2012, from http://www.cotton.org/econ/ prices/monthly.cfm. Accessed 15 Jan 2015.

Scheffer, M., \& Duineveld, M. (2004). Final demise or regeneration? The Dutch case. Journal of Fashion Marketing and Management, 8, 340-349.

Seshadri, S. (2005). Sourcing strategy: Principles, policy and designs. New York: Springer

Stevens, J. (2003). Nike, Inc. et al., petitioners v. Mark Kasky on wirt of certiorari to the Supreme Court of California. Retrieved March 3 11, 2014, from http://www.law.cornell.edu/supct/html/02-575.ZC.html. Accessed 15 Jan 2015.

Su, J., Dyer, C. L., \& Gargeya, V. B. (2009). Strategic sourcing and supplier selection in the US textile-apparel—retail supply network. Clothing and Textiles Research Journal, 27(2), 83-97.

Taplin, I., \&Winterton, J. (2004). The European clothing industry: meeting the competitive challenge. Journal of Fashion Marketing and Management, 8, 256-261. 
US Federal Trade Commission. (2010). Press releases. Retrieved December 16, 2014, from FTC warns 78 retailers, including Wal-Mart, Target, and Kmart, to stop labeling and advertising rayon textile products as "Bamboo". http://www.ftc. gov/news-events/press-releases/2010/02/ftc-warns-78-retailers-including-wal-mart-target-kmart-stop. Accessed 15 Jan 2015.

Wilson, L. (2002). Technology, dress, and social change. Proceedings of the international Costume Conference (pp. 3-9).

Submit your manuscript to a SpringerOpen ${ }^{\circ}$ journal and benefit from:

- Convenient online submission

- Rigorous peer review

- Immediate publication on acceptance

- Open access: articles freely available online

- High visibility within the field

Retaining the copyright to your article

Submit your next manuscript at $>$ springeropen.com 